\title{
GLAUCOUS GULLS AT PRINCE ALBERT, SASKATCHEWAN
}

\author{
by E. D. Beacham, Prince Albert
}

At about $4: 30$ p.m. on the afternoon of October 23, 1969, I observed a large gull with white wing tips flying north from the garbage dump on the grounds of the Saskatchewan Penitentiary at Prince Albert to the North Saskatchewan River. A check at the garbage dump the following morning, October 24, by my wife and myself, revealed the presence of two Glaucaus Gulls (Larus hyberboreus) both in the pale buffy first-year plumage. These birds were easily distinguished from the Ring-billed and juvenile Herring Gulls by their larger size and by their colour.

During the afternoon Mr. J. Norfield, my wife and myself, in company with Conservation Officer Ray Puddicombe, got permission from the Warden of the Penitentiary to drive into the garbage dump, and one of the gulls was collected and sent to the Saskatchewan Museum of Natural History, Regina. This constitutes the second specimen record for Saskatchewan, the first specimen having been taken by $R$. W. Nero at Lorado near Uranium City on June 13, 1960 (Nero. 1963. Birds of the Lake Athabasca region, Sask.). Two other sight records have been reported: one at Lake Athabasca on May 25, 1960, (Nero, op. cit.), and one on May 27, 1964 at Wollaston Lake (Nero, 1967. The birds of northeastern Saskatchewan). The Prince Albert record is the most southerly Saskatchewan record, being 400-450 miles south of earlier records.

The remaining Glaucous Gull was seen again the following morning, October 25, by my wife and me, and again the same afternoon by myself, Dr. R. Austin and Mr. Frank Morton of Prince Albert.

It is interesting to speculate on the reason for the occurrence of this Arctic gull as far south as Prince Albert. It may be of significance that their arrival coincided with a snow storm which hit central Saskatchewan on October 20. Other recent observations of the Glaucous Gull at this latitude in the Prairie Provinces are from Beaverhills Lake, Alberta, May 14, 1966 (Smith, Blue Jay, September 1967) and The Pas, Manitoba, October 15, 1946 (Waller, Blue Jay, September 1967).

\section{AWARD WINNER, MANITOBA PROVINCIAL EXHIBITION, 1969}

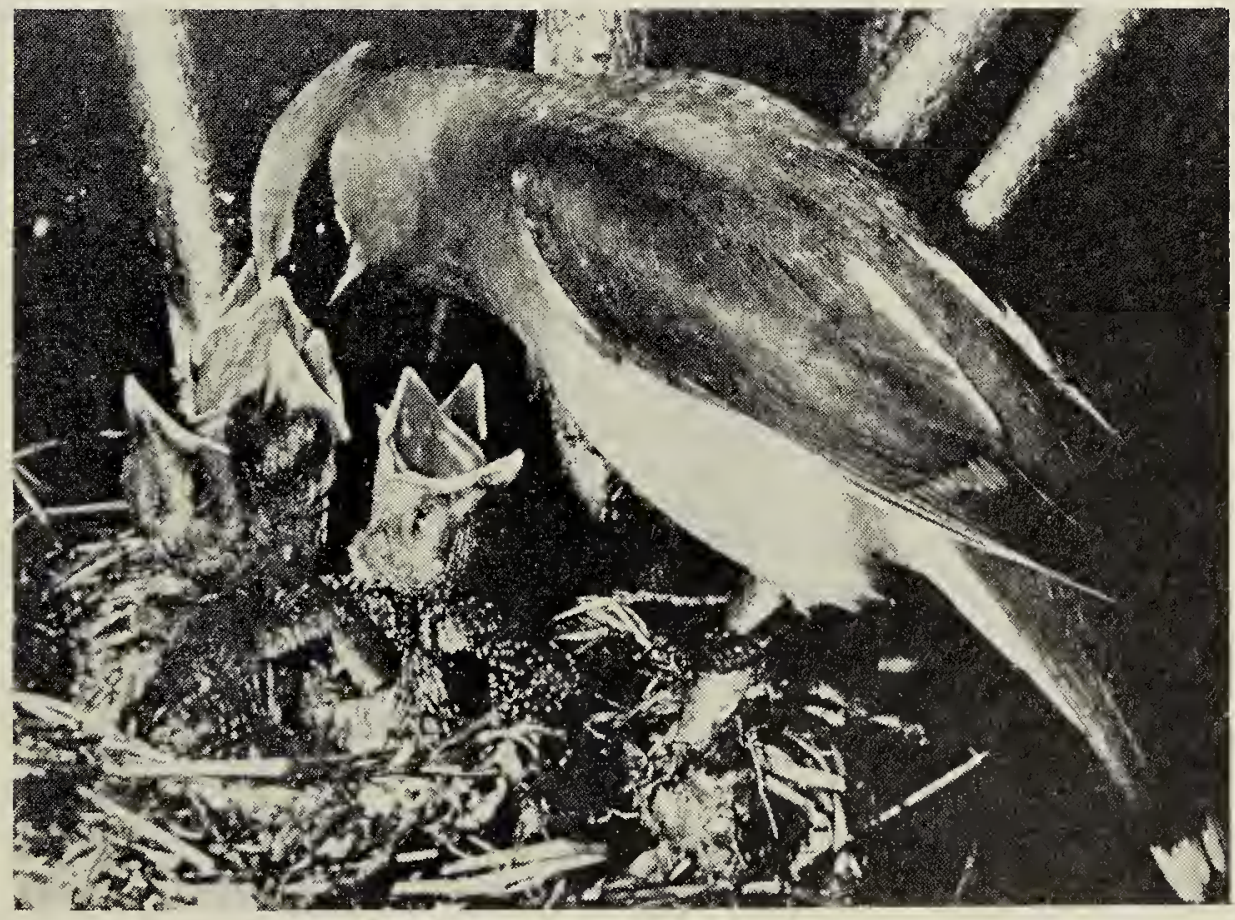

Color Photo by Chris Rees, Edmonton

Cedar Waxwing feeding her young 